\title{
Local Taxation, Private-Public Consumption Complementarity, and the Optimal Number of Jurisdictions
}

\author{
Gerasimos T. Soldatos \\ American University of Athens, Athens, Greece \\ Email: soldgera@yahoo.com
}

Received 13 October 2014; revised 10 November 2014; accepted 3 December 2014

Copyright (C) 2014 by author and Scientific Research Publishing Inc.

This work is licensed under the Creative Commons Attribution International License (CC BY).

http://creativecommons.org/licenses/by/4.0/

(c) () Open Access

\begin{abstract}
Viewing local finances under the approach to private-public consumption complementarity, we conclude that foot voting and tax competition become extinct when the (capital) tax structure across jurisdictions is the one forging close ties between the burgher and his/her jurisdiction. The attachment of the burgher to the local public goods offered and to the local business activity prevents labor and capital mobility. The optimal number of jurisdictions is that which is conducive to the adoption of that local taxation that fosters such an attachment; taxation made possible by capitalizing upon private-public consumption complementarity. The intuitive appeal of this result is then contemplated within the broader framework of fiscal policymaking accommodative of citizen heterogeneity. In view of complementarity, there appears to be scope for decentralized treatment of citizen preferences via the localities, leaving the treatment of endowment differences to the central government.
\end{abstract}

\section{Keywords}

Local Taxation, Private-Public Consumption Complementarity, Citizen Heterogeneity, Burgher-Community Attachment

\section{Introduction}

In so far as the optimal local public goods provision-tax rate mix is concerned, the Tiebout [1] hypothesis maintains that citizens accommodate their preferences for this mix by "foot voting” or the same, through interjurisdictional migration, i.e. by settling down each to his or her most preferred jurisdiction, with the optimal number of communities being shaped by this sorting out of citizen preferences. In so far as the mix regarding local pri- 
vate goods supply-tax rates is concerned, the confrontation of wasteful interjurisdictional tax competition to attract private capital presupposes a limited only number of localities at the Nash-Cournot equilibrium (Hoyt [2]). The same result obtains when "the levels of taxation and the local public good varieties provided within jurisdictions are selected by majority voting” (Perroni and Scharf [3]). Which is then the optimal number of localities, the one that would not change in response to tax competition?

Assuming that the relevant tax is that on capital, this question translates to finding the capital tax structure across communities, which would not induce burgher relocation, and from which no community would have an incentive to deviate. Private investments in a locality create jobs and incomes to be consumed while public expenditures by a locality aim at satisfying burgher demand for the goods provided through them. Evoking upon the complementarity between private and public consumption in the sense of private consumption responding positively to an increase in public spending (Fiorito and Kollintzas [4], Linnemann [5], Bouakez and Rebei [6], Ganelli and Tervala [7]), this paper maintains that the optimum tax is simply the one which maximizes the individual utility from these two consumption types on the proviso that this is the aim of local governments as well. Much more so when complementarity (as opposed to substitutability) is certainly the case with the public goods that are rival in consumption and whose positive externalities depend on distributional and demographic characteristics as is this case with the local public goods.

From still another point of view, as soon as term "public consumption" refers to consumption of public goods and hence, to the public investments made to produce them, we do know from Ogura and Yohe [8] originally and Bucci and Del Bo [9] more recently that public and private capital complement each other. At the local level, this implies that a local public project is expected to raise the productivity of the private industry situated in the same locality. Taxes are a distortion but under capital complementarity, an underinvestment by the private sector may be counterbalanced by public investment raising the marginal product of private capital and encouraging thereby the inflow of such capital. The subsequent public investment externalities-spillovers at the general equilibrium setting are expected, following Figuières et al. [10], to have subsided at interjurisdictional equilibrium while interjurisdictional cooperation to increase growth rates should be sought only if the consumption preferences regarding "domestic and foreign goods" allow so.

In what follows, what is done analytically is to merge Hoyt's [2] model of the local finances with Ganelli and Tervala's [7] approach to private-public consumption complementarity. What we find then is that foot voting and tax competition become extinct when the tax structure across jurisdictions is the one forging close local ties for the burgher. These are ties shaped by the private-public consumption complementarity despite different tastes in a given community. The intuitive appeal of this result is then contemplated within the broader framework of fiscal policymaking accommodative of citizen heterogeneity. Complementarity allows communities to handle efficiently heterogeneity in preferences, leaving endowment differences to be dealt with by the state.

\section{The Model}

We shall first model the locality in line with Hoyt [2] to combine it next with the modeling of the burgher following Ganelli and Tervala [7].

\subsection{The Locality}

A single private good is assumed to be produced in a given locality, which is providing a single public good, based both production processes on mobile labor and capital. Let the local government budget constraint be

$$
T_{i} \frac{K_{i}}{L_{i}}=\frac{G_{i}}{L_{i}} \Rightarrow T_{i}=\frac{G_{i}}{K_{i}}
$$

where $T_{i}$ is the tax per laborer $L$ on the capital $K_{i}$ of the $i$ th jurisdiction providing the local public good $G_{i}$. The ratio $G_{i} / K_{i}$ gives the mix of public and private investment in $i$. Abstracting from differences in the production technologies used locally, jurisdictional output per capita is $Y_{i} / L_{i}=f\left(K_{i} / L_{i}\right)$ or $y_{i}=f\left(k_{i}\right)$, but total capital

$$
\sum_{i} K_{i}=\bar{K}
$$

and labor $\sum_{i} L_{i}=\bar{L}$ are fixed so that total per capita output $\sum_{i}\left(Y_{i} / L_{i}\right)=\bar{Y} / \bar{L}=f(\bar{K} / \bar{L})$ is given too. Free 
movement of capital and labor implies equalization across jurisdictions of the rate of return $r$ on capital so that

in each locality. From (2) one obtains that

$$
\partial f / \partial k_{i}=T_{i}+r
$$

$$
\frac{\partial k_{1}}{\partial r}+\frac{\mathrm{d} r}{\mathrm{~d} T_{1}} \sum_{i} \frac{\partial k_{i}}{\partial r}=0 \Rightarrow \frac{\mathrm{d} r}{\mathrm{~d} T_{1}}=-\frac{\partial k_{1}}{\partial r} / \sum_{i} \frac{\partial k_{i}}{\partial r} \equiv-S_{1}
$$

$s_{1}$ being presumably the market share of jurisdiction 1 , while $\partial k_{i} / \partial r$ is the derivative of the $i$ th jurisdiction's demand for capital with respect to the price $\rho=r$ of capital at equilibrium. So, if there are two only jurisdictions, 1 and 2, the movement of capital from 1 to 2 in response to a tax increase in 1 will be captured by

and

$$
\frac{\mathrm{d} k_{1}}{\mathrm{~d} T_{1}}=\left(1-s_{1}\right) \frac{\partial k_{1}}{\partial r}=s_{2} \frac{\partial k_{1}}{\partial r}
$$

Consequently, from (1) and (5),

$$
\frac{\mathrm{d} k_{2}}{\mathrm{~d} T_{1}}=-S_{1} \frac{\partial k_{1}}{\partial r}
$$

$$
\frac{\mathrm{d} g_{1}}{\mathrm{~d} T_{1}}=k_{1}+T_{1} \frac{\mathrm{d} k_{1}}{\mathrm{~d} T_{1}}=k_{1}+T_{1}\left(1-s_{1}\right) \frac{\partial k_{1}}{\partial r} \Rightarrow \frac{\mathrm{d} g_{1}}{\mathrm{~d} T_{1}}=k_{1}\left[1+T_{1}\left(1-s_{1}\right) \frac{\partial k_{1} / \partial r}{k_{1}}\right]
$$

or noticing that the elasticity of the demand for $K_{1}$ is $e_{1}=\left(\partial K_{1} / \partial r\right) / K_{1}\left(T_{i}+r\right)$,

$$
\frac{\mathrm{d} g_{1}}{\mathrm{~d} T_{1}}=k_{1}\left[1+\frac{T_{1}\left(1-s_{1}\right) e}{\left(T_{i}+r\right)}\right]
$$

where $g_{i}=G_{i} / L_{i}$. Finally, private consumption per capita $c_{i}=C_{i} / L_{i}$ is given by

$$
c_{i}=y_{i}-\left(T_{i}+r\right) k_{i}+r s_{i} \bar{k}
$$

where the last term is capital income; $\bar{k}=\bar{K} / \bar{L}$. From (8) and (3) one obtains that

$$
\frac{\mathrm{d} c}{\mathrm{~d} T_{i}}=-k_{i}
$$

which when combined with (7), yields that

$$
\frac{\mathrm{d} g_{1}}{\mathrm{~d} c_{1}}=-\left[1+\frac{T_{1}\left(1-s_{1}\right) e}{\left(T_{i}+r\right)}\right] .
$$

\subsection{The Burgher}

Eichner and Runkel [11] argue that "If the capital supply elasticity is strictly positive,... capital tax rates are inefficiently low in... decentralized equilibrium.” This should not be the case under general equilibrium, prompting in turn a discussion of the burgher as follows. Let the utility function of the typical citizen of the $i$ th jurisdiction be

$$
U_{i}=\ln \left(c_{i}-h_{i} g_{i}\right)-\frac{1}{1+v_{i}}\left(y_{i}\right)^{1+v_{i}}
$$

where ln denotes the natural logarithm, the coefficient $h$ is positive, capturing the complementarity between $C$ and $G$, (an increase in $G$ increases the marginal utility of $C$ given the negative sign accompanying the positive $h$ ), while the parameter $v \geq 0$ gives the elasticity of the marginal disutility of producing $Y$ with respect to $Y$. The disutility of producing $Y$ in a given jurisdiction $i$ refers to the deviation from the optimal capital-labor ratio following labor relocation. $h$ and $v$ reflect the burgher's attitude towards local public goods and private capital, respectively. Letting $P$ be the equilibrium price level,

$$
\left(y_{i}\right)^{v_{i}}=\mu P
$$


where

$$
\mu=\left[P\left(c_{i}-h_{i} g_{i}\right)\right]^{-1}
$$

as it obtains from the household maximization problem given the budget constraint

$$
P c_{i}=P y_{i}-P T_{i} k_{i}
$$

where $T_{i}$ satisfies of course (1), i.e. local budgets are assumed to be balanced. That is,

$$
\left(y_{i}\right)^{v_{i}}=\left(c_{i}-h_{i} g_{i}\right)^{-1}
$$

meaning that the disutility from trying to restore the optimal local capital-labor ratio following say emigration from a locality, should be equal to the utility derived from the consumption of one more unit produced towards the restoration of the ratio. Log-linearized, (13) becomes $v_{i} \hat{y}_{i}=-\left(\hat{c}_{i}+h_{i} \hat{g}_{i}\right)$, which in view of the equilibrium relationship $\hat{y}_{i}=\hat{c}_{i}+\hat{g}_{i}$, yields that

$$
\hat{c}_{i}=-\left(\frac{v_{i}-h_{i}}{v_{i}+1}\right) \hat{g}_{i}
$$

\subsection{Analysis}

Now, note that from (14),

$$
\frac{\mathrm{d} \hat{g}_{i}}{\mathrm{~d} \hat{c}_{i}} \equiv \frac{\mathrm{d} g_{i}}{\mathrm{~d} c_{i}} \frac{c_{i}}{g_{i}}=-\frac{v_{i}+1}{v_{i}-h_{i}}
$$

which when combined with (10) gives that

$$
\left(\frac{v_{i}+1}{v_{i}-h_{i}}\right) \frac{c_{1}}{g_{1}}=\left[1+\frac{T_{1}\left(1-s_{1}\right) e}{\left(T_{i}+r\right)}\right]
$$

in so far as jurisdiction 1 is concerned. Solving (16) for $s_{1}$ and differentiating with respect to $T_{i}$, the derivative $\mathrm{d} s_{1} / \mathrm{d} T_{i}$ will be zero, i.e. changes in $T_{i}$ will have no effect on $s_{1}$ as should be the case at equilibrium, iff

$$
c_{i}=\left(\frac{v_{i}-h_{i}}{v_{i}+1}\right) g_{i}
$$

This in conjunction with (1) imply that one property of the optimal tax structure should be that

$$
T_{i}=\left(\frac{v_{i}+1}{v_{i}-h_{i}}\right) \frac{c_{i}}{k_{i}}
$$

Or, inserting (14) in $\hat{y}_{i}=\hat{c}_{i}+\hat{g}_{i}$, gives that

$$
\hat{y}_{i}=\left(\frac{h_{i}+1}{v_{i}+1}\right) \hat{g}_{i} \Rightarrow y_{i}=g_{i}^{\frac{h_{i}+1}{v_{i}+1}}
$$

which by (1) implies that

$$
T_{i}=\frac{y_{i}^{\frac{v_{i}+1}{h_{i}+1}}}{k_{i}}
$$

Note that from (17) or (18), $T_{i}>0$ iff $v_{i}>h_{i}$, and hence, $\mathrm{d} \hat{y}_{i} / \mathrm{d} \hat{g}_{i}<1$. A third expression for $T_{i}$ is obtained by inserting (17) in (8) given also (1):

$$
T_{i}=\frac{\left[y_{i}-r\left(k_{i}+s_{i} \bar{k}\right)\right]\left(v_{i}+1\right)}{k_{i}\left(2 v_{i}-h_{i}+1\right)}
$$

This is a more complicated expression but it does suggest that $2 v_{i}>h_{i}-1$ is too a condition for $T_{i}>0$. And, 
since $v_{i} \geq 0$, a third condition is that $h_{i}>1$. This coupled with the restriction that $v_{i}>h_{i}$, implies that both $h$ and $v$ should exceed 1 .

In words, foot voting becomes meaningless if the burgher "feels" much attached to the local entrepreneurial activity and tax competition becomes futile if the burger feels the same attached to the local public goods supplied by its jurisdiction. And, the complementarity between private and public consumption ensures that "the two feelings" work in the same direction, which the interjurisdictional tax structure comes to exploit in order maximize attachment and minimize subsequently migration and capital flight. Two burghers differing in tastes may be feeling the same attachment to a given locality, which is this attachment that according to (18), (19), or (20) should be the target of policy, not the satisfaction of individual preferences per se.

\section{Concluding Remarks}

The nonlinearity, the Mirrleesian character of the optimal tax structure across jurisdictions prompts one to think of this structure as a decentralized fiscal vehicle accommodating heterogeneity in $v$ 's and $h$ 's. It is a vehicle that cannot be provided by the central government but which comes to complement the da Costa-Werning Mirrleesian framework in which the central government can accommodate the differences in earning ability (Gahvari and Micheletto [12]). There are the advantages of such a scheme: First, localities are absolved from redistributive tasks, which may certainly become responsible for regional shifts in population and economic activity (see e.g. Bahl [13]). Local taxation in the sense developed earlier, can be optimal only from the viewpoint of allocational objectives, i.e. of influencing the geographical pattern of private investment and determining the level and mix of local public goods expenditure. Second, the framework of national-subnational government interaction becomes well defined, assigning the redistributive and stabilization objectives exclusively to the state and minimizing the need for central authority intervention in the local finances. And third, the proposed scheme weakens further the need to take recourse to the redistributive power of monetary policy and thereby to decisionmaking on the part of a non-elected central banker.

Of course, it all depends on whether private consumption and government spending are actually positively related or not. This is a matter of ongoing theoretical and empirical investigation, which appears to confirm this hypothesis and needs to expand to local finance as well. What our discussion herein suggests towards this direction is that the close burgher-community ties may be a reason for the external habit formation contemplated for example by Ravn, Schmitt-Grohe and Uribe [14]. Note that it has been a discussion assuming away public-good and factor congestion and the need for such local taxation on mobile firms and households that would internalize marginal crowding costs. Once the matter of congestion is addressed, our conclusions here would continue holding if this first-best local policymaking was possible, and they would be strengthened even further in a secondbest setting, because as Wellisch and Hülshorst [15] emphasize, the second-best is one in which: "[M]igration does not only reveal the preferences for local public goods, as suggested by Tiebout [1]. Rather, local governments have incentives to consider these preferences in a socially efficient way even if they only rely on distortionary taxes”.

We conclude this brief essay by noting that at this abstract level of our discussion, only a qualitative description of the optimal number of jurisdictions has been provided; numerical calibrations would certainly produce definite results, but would depend on the market size assumed, which is one aspect of the issue under investigation that is being researched by itself (see e.g. Casella [16], Casella and Feinstein [17]). Another limitation of the calibration would be the absence analytically of a differentiation between first- and second-order administrative subdivisions, between say provinces and municipalities, respectively, which is an issue addressed only recently by Auffhammer and Carson [18]. Finally, only one tax is assumed as policy instrument available to localities while the presence of matching grants on the part of central government to correct for interjurisdictional spillovers (Figuières and Hindriks [19], Hoyt [20]) is disregarded, too.

\section{Acknowledgements}

I am grateful to an anonymous referee for useful comments and suggestions.

\section{References}

[1] Tiebout, C. (1956) A Pure Theory of Local Expenditures. Journal of Political Economy, 64, 416-424. 
http://dx.doi.org/10.1086/257839

[2] Hoyt, W. (1991) Property Taxation, Nash Equilibrium and Market Power. Journal of Urban Economics, 30, $123-131$. http://dx.doi.org/10.1016/0094-1190(91)90049-D

[3] Perroni, C. and Scharf, K.A. (2001) Tiebout with Politics: Capital Tax Competition and Constitutional Choices. Review of Economic Studies, 68, 133-154. http://dx.doi.org/10.1111/1467-937X.00163

[4] Fiorito, R. and Kollintzas, T. (2004) Public Goods, Merit Goods, and the Relation between Private and Government Consumption. European Economic Review, 48, 1367-1398. http://dx.doi.org/10.1016/j.euroecorev.2004.01.004

[5] Linnemann, L. (2006) The Effect of Government Spending on Private Consumption: A Puzzle? Journal of Money, Credit and Banking, 38, 1715-1735. http://dx.doi.org/10.1353/mcb.2006.0094

[6] Bouakez, H. and Rebei, N. (2007) Why Does Private Consumption Rise after a Government Spending Shock? Canadian Journal of Economics/Revue Canadienne d'Economique, 40, 954-979. http://dx.doi.org/10.1111/j.1365-2966.2007.00438.x

[7] Ganelli, G. and Tervala, J. (2009) Can Government Spending Increase Private Consumption? The Role of Complementarity. Economics Letters, 103, 5-7. http://dx.doi.org/10.1016/j.econlet.2009.01.007

[8] Ogura, S. and Yohe, G. (1977) The Complementarity of Public and Private Capital and the Optimal Rate of Return to Government Investment. Quarterly Journal of Economics, 91, 651-666. http://dx.doi.org/10.2307/1885887

[9] Bucci, A. and Del Bo, C. (2009) On the Interaction between Public Investment and Private Capital in Economic Growth. UNIMI-Research Papers in Economics, Business, and Statistics, Universitá degli Studi di Milano Unimi1092, Universitá degli Studi di Milano, Milano.

[10] Figuières, C., Prieur, F. and Tidball, M. (2013) Public Infrastructure, Non-Cooperative Investments, and Endogenous Growth. Canadian Journal of Economics/Revue Canadienne d'Economique, 46, 587-610. http://dx.doi.org/10.1111/caje.12024

[11] Eichner, T. and Runkel, M. (2012) Interjurisdictional Spillovers, Decentralized Policymaking, and the Elasticity of Capital Supply. American Economic Review, 102, 2349-2357. http://dx.doi.org/10.1257/aer.102.5.2349

[12] Gahvari, F. and Micheletto, L. (2012) Monetary Policy and Redistribution: What Can or Cannot Be Neutralized with Mirrleesian Taxes. Uppsala Center for Fiscal Studies Working Paper 2012:5. http://ucfs.nek.uu.se/

[13] Bahl, R. (1984) Financing State and Local Government in the 1980s. Oxford University Press, New York.

[14] Ravn, M., Schmitt-Grohe, S. and Uribe, M. (2006) Deep Habits. Review of Economic Studies, 73, $195-218$. http://dx.doi.org/10.1111/j.1467-937X.2006.00374.x

[15] Wellisch, D. and Hülshorst, J. (2000) A Second-Best Theory of Local Government Policy. International Tax and Public Finance, 7, 5-22. http://dx.doi.org/10.1023/A:1008749628237

[16] Casella, A. (2001) The Role of Market Size in the Formation of Jurisdictions. Review of Economic Studies, 68, 83-108. http://dx.doi.org/10.1111/1467-937X.00161

[17] Casella, A. and Feinstein, J.S. (2002) Public Goods in Trade: On the Formation of Markets and Jurisdictions. International Economic Review, 43, 437-462. http://dx.doi.org/10.1111/1468-2354.t01-1-00022

[18] Auffhammer, M. and Carson, R.T. (2009) Exploring the Number of First-Order Political Subdivisions across Countries: Some Stylized Facts. Journal of Regional Science, 49, 243-261. http://dx.doi.org/10.1111/j.1467-9787.2008.00583.x

[19] Figuières, C. and Hindriks, J. (2001) Matching Grants and Ricardian Equivalence. Center for Operations Research and Econometrics (CORE) Discussion Paper No 2001048, Université catholique de Louvain, Louvain-la-Neuve.

[20] Hoyt, W. (2005) The Assignment and Division of the Tax Base in a System of Hierarchical Governments. Institute for Federalism and Intergovernmental Relations Working Paper No 2005-07, University of Kentucky, Lexington. 
Scientific Research Publishing (SCIRP) is one of the largest Open Access journal publishers. It is currently publishing more than 200 open access, online, peer-reviewed journals covering a wide range of academic disciplines. SCIRP serves the worldwide academic communities and contributes to the progress and application of science with its publication.

Other selected journals from SCIRP are listed as below. Submit your manuscript to us via either submit@scirp.org or Online Submission Portal.
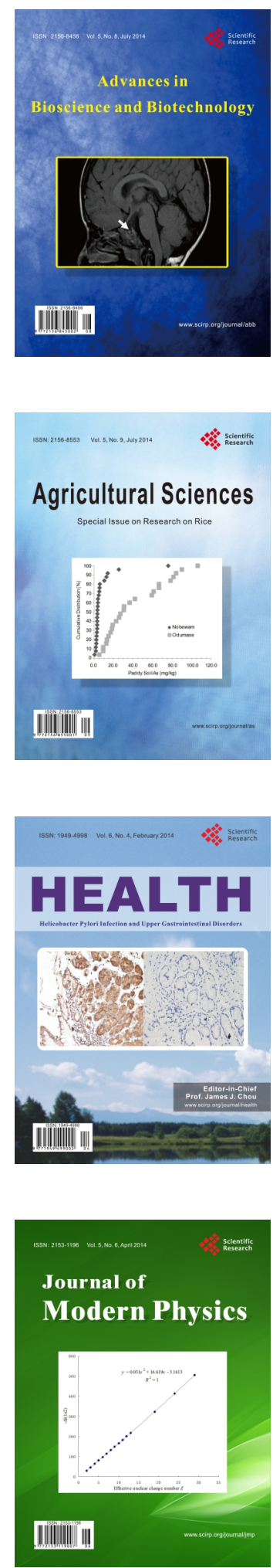
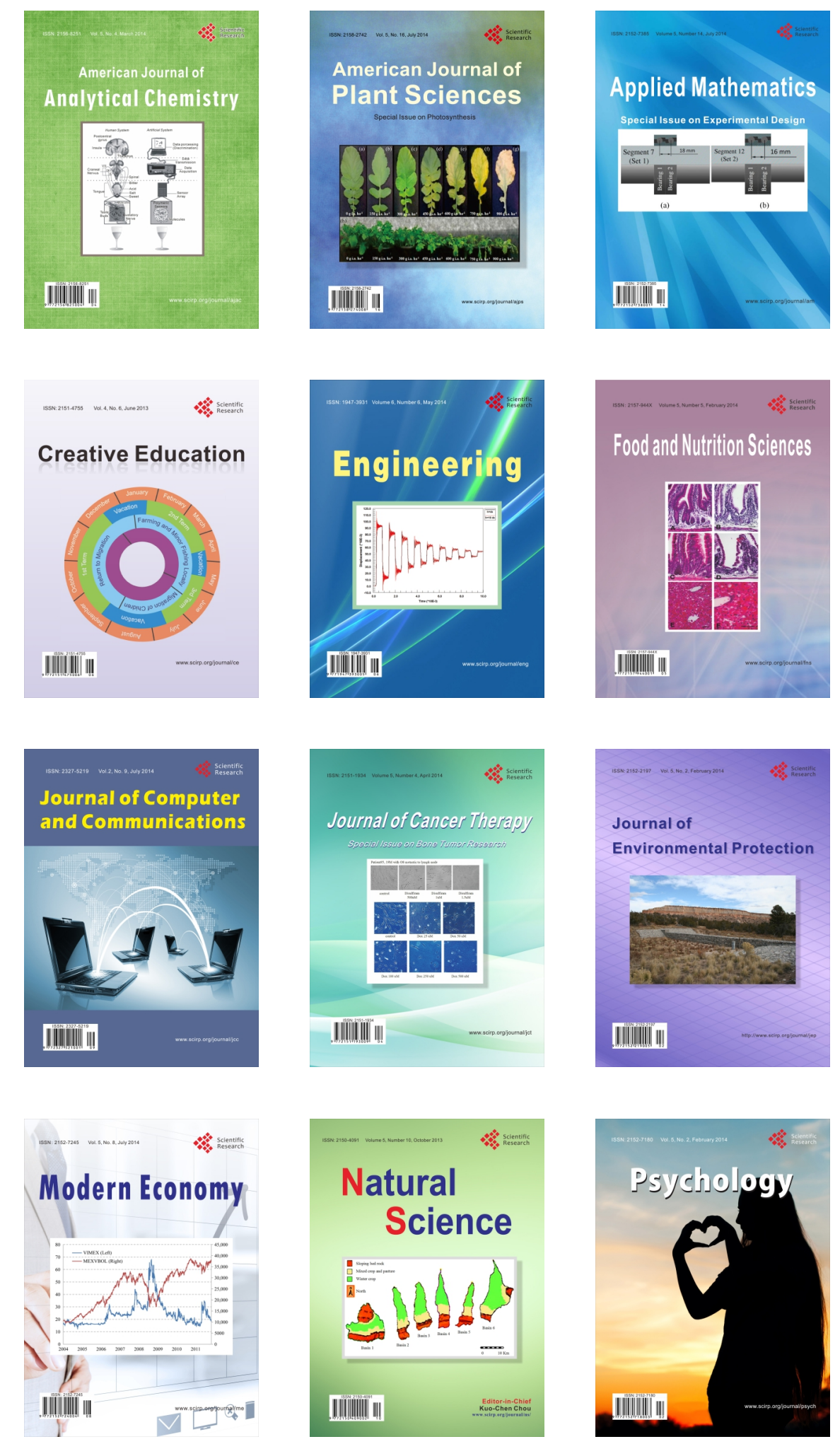